J. Clin. Chem. Clin. Biochem.

Vol. 18, 1980, pp. 413-421

\title{
Single-Isotope Enzymatic Derivative Method for Measuring Catecholamines in Human Plasma ${ }^{1}$ )
}

\author{
By J. Bosak, E. Knoll, D. Ratge and H. Wisser \\ Department of Clinical Chemistry, Robert-Bosch-Krankenhaus, Stuttgart
}

(Received October 1, 1979/January 21, 1980)

Summary: The radioenzymatic determination of plasma catecholamines with a modification of the method of $d a$ Prada \& Zürcher ((1976), Life Sci 19, 1161-1174) is described. The several reaction steps were optimized with respect to the quantities of substrate and enzyme, and reaction time. There were particular methodological difficulties concerning the blanks, which were determined by using sodium metaperiodate-oxidized plasma. The reliability criteria of the method were determined. Coefficients of variation between 3.4 and $8.6 \%$ were found for the intra-assay variability of $10 \mathrm{pg}$ of norepinephrine and $3 \mathrm{pg}$ of epinephrine or dopamine, resp. The recoveries of the three catecholamines ranged from $88-93 \%$. The detection limits were calculated from the standard deviation of the blanks and amounted to $12 \mathrm{ng} / \mathrm{l}$ (norepinephrine), $6 \mathrm{ng} / \mathrm{l}$ (dopamine) and $3 \mathrm{ng} / \mathrm{l}$ (epinephrine). The method was used for the analysis of plasma samples from patients. In a further investigation we examined the stability of plasma catecholamines stored at different temperatures. It was found that samples can be stored for 1-2 hours at room temperature and for several weeks at $-27^{\circ} \mathrm{C}$ without losses in catecholamine content.

\section{Enzymatische Einisotopenderivat-Methode zur Bestimmung der Catecholamine im Plasma}

Zusammenfassung: Die radioenzymatische Bestimmung der Catecholamine im Plasma mit einer Modifikation der Methode von da Prada \& Zürcher ((1976), Life Sci 19, 1161-1174) wird beschrieben. Die einzelnen Reaktionsschritte wurden bezüglich der Substrat- und Enżymmenge sowie der Reaktionsdauer optimiert. Besondere methodische Schwierigkeiten gab es bei den Leerwerten, für die mit Natriummetaperjodat oxidiertes Plasma eingesetzt wurde. Die Zuverlässigkeitskriterien der-Methode wurden ermittelt. Die Streuung in der Serie für $10 \mathrm{pg}$ Noradrenalin und jeweils $3 \mathrm{pg}$ Adrenalin und Dopamin lag zwischen 3,4 und 8,6\%. Die Wiederfindung bei Aufstockexperimenten betrug 88-93\%. Aus der Streuung der Leerwerte wurden die folgenden Nachweisgrenzen berechnet: Noradrenalin $12 \mathrm{ng} / \mathrm{l}$, Dopamin $6 \mathrm{ng} / \mathrm{l}$ und Adrenalin $3 \mathrm{ng} / 1$. Plasmaproben von Patienten wurden mit dem Verfahren analysiert. Außerdem wurde die Stabilität der Catecholamine im Plasma bei verschiedenen Temperaturen untersucht. Nach den Ergebnissen dieser Versuchsreihe können Plasmaproben 1-2 Stunden bei Raumtemperatur und mehrere Wochen bei $-27^{\circ} \mathrm{C}$ ohne Verluste an Catecholaminen aufbewahrt werden.

\section{Introduction}

The development of a double-isotope derivative method by Engelman and coworkers $(1,2)$ was an important methodological advance in the field of catecholamine analysis. With this method epinephrine and norepinephrine in plasma could be determined specifically; the precision, however, was unsatisfactory, and the epinephrine concentrations in human plasma were near the detection limit of the assay.

The method is based on the enzymatic conversion of the catecholamines with $S$-adenosyl- $L$-methionine-

1) This investigation was supported by the Robert Bosch Stiftung, Stuttgart (FRG). (methyl $\left[{ }^{14} \mathrm{C}\right]$ ) and catechol-O-methyltransferase to their 3-0-methylated derivatives. Losses in the course of the assay are corrected for by addition of tritiated epinephrine and norepinephrine to the plasma. Passon \& Peuler (3) introduced an important modification of this method by using S-adenosyl- $L$-me thionine(methyl $\left[{ }^{3} \mathrm{H}\right]$ ) which has a considerably higher specific activity than the $S$-adenosyl- $L$-methionine(methyl$\left.\left[{ }^{14} \mathrm{C}\right]\right)$. This resulted in a 10-fold improvement of the assay sensitivity so that the sample volume could be reduced from $10 \mathrm{ml}$ to less than $1 \mathrm{ml}$ plasma. The losses were corrected for by use of internal standards. Dopamine in plasma was first determined radioenzymatically by Coyle \& Henry (4). In the last few years a series of reports has appeared dealing with the radio- 
enzymatic determination of the catecholamines $(5-13)$. The present report describes a modification of the da Prada-Zürcher-method (6); the conditions of the enzymatic methylation were investigated, the reliability criteria were determined, and applicability to the analysis of human plasma was examined.

\section{Materials and Methods \\ Principle of the method}

By modifying the procedure of da Prada \& Zürcher (6), a radioenzymatic method was developed for the simultaneous determination of epinephrine, norepinephrine and dopamine. It is based on the enzy matic 3-0-methylation of the three catecholamines by catechol-O-methyltransferase (EC 2.1.1.6) in the presence of S-adenosyl-methionine(methyl[ $\left.{ }^{3} \mathrm{H}\right]$ ) of a very high specific activity $(2.04-3.15 \mathrm{TBq} / \mathrm{mmol}=55-85$ $\mathrm{Ci} / \mathrm{mmol})$ to $\left[{ }^{3} \mathrm{H}\right]$ metanephrine, $\left[{ }^{3} \mathrm{H}\right]$ normetanephrine and $\left[{ }^{3} \mathrm{H}\right]$ methoxy tyramine respectively. After addition of sodium tetraphenylborate the tritiated 3-methoxy-derivatives are extracted into die thyl ether as tetraphenylborate-complexes. They are then nearly quan titatively re-extracted into hydrochloric acid. The reaction products are separated by thin-layer chromatography. The periodate oxidation of $\left[{ }^{3} \mathrm{H}\right]$ metanephrine and $\left[{ }^{3} \mathrm{H}\right]$ normetanephrine to vanillin results in a further reduction of the blanks. $\left[{ }^{3} \mathrm{H}\right]$ methoxytyramine lacking the $\beta$-hydroxyl group, does not oxidize under these conditions. It is therefore converted into the diacetyl derivative by reaction with acetic anhydride. The resulting compounds are extracted into toluene and the tritium activity is counted in a liquid scintillation spectrometer. Figure 1 shows the principle of the method.

\section{Description of the procedure}

Preparation of catechol-O-methyltransferase (EC 2.1.1.6) from rat liver according to Axelrod \& Tomchick (14)

8 rats were decapitated, the livers $(60-70 \mathrm{~g})$ immediately removed and transferred into the 4 -fold volume $(w / v)$ of icecold isotonic $\mathrm{KCl}$-solution. All further purification procedures are carried out at $0-5^{\circ} \mathrm{C}$. The liver is minced and homogenized with the KCl-solution, followed by $30 \mathrm{~min}$ centrifugation at $80000 \mathrm{~g}$.

The supernatant is filtered, adjusted to $\mathrm{pH} 5$ with $1 \mathrm{~mol} / 1$ acetic acid and stirred for $20 \mathrm{~min}$. The suspension is centrifuged at $10000 \mathrm{~g}$ for $15 \mathrm{~min}$. The precipitate is discarded, the supernatant ist fractionated with ammonium sulfate. Degree of saturation 0-0.3: $0.174 \mathrm{~g}$ ammonium sulfate are added per $\mathrm{ml}$ supernatant; the mixture is stirred for $20 \mathrm{~min}$ and centrifuged at $10000 \mathrm{~g}$ for $30 \mathrm{~min}$. The precipitate is discarded. Degree of saturation 0.3-0.5:0.177 $\mathrm{g}$ ammonium sulfate are added per $\mathrm{ml}$ supernatant; the mixture is again stirred for $20 \mathrm{~min}$ followed by $30 \mathrm{~min}$ centrifugation at $18000 \mathrm{~g}$. The supernatant is discarded and the precipitate is dissolved in $30-40 \mathrm{ml}$ of sodium phosphate buffer $(1 \mathrm{mmol} / \mathrm{l})$ $\mathrm{pH}$ 7. The solution is dialyzed for $12 \mathrm{~h}$ against $1: 5 \mathrm{l}$ of the phosphate buffer containing $0.1 \mathrm{mmol} / 1$ dithiothreitol. The precipitate formed during dialy sis is centrifuged for $15 \mathrm{~min}$ at $10000 \mathrm{~g}$. The supernatant $(40 \mathrm{ml})$ is dispensed in $1 \mathrm{ml}$-portions in disposable containers (Eppendorf tube) and stored at $-27^{\circ} \mathrm{C}$ until use. The protein concentration of the solution is $\mathbf{1 4 . 9}$ $\mathrm{mg} / \mathrm{ml}$ (biuret-method).

\section{Reagents and solutions}

Ethyleneglycol-bis ( $\beta$-aminoethylether) $\mathbf{N}, N^{\prime}$-tetraacetic acid (EGTA), $D L$-norme tanephrine hydrochloride, $D L$-metanephrine hydrochloride, 3-methoxyty ramine hydrochioride, $D L$-dithiothreitol: Sigma Chemie, Taufkirchen, FRG; $L$ norepinephrine hydrogentartrate: Fluka, Buchs/Switzerland; $L$ epinephrine base, glutathione red.: Merck, D̆armstadt, FRG;

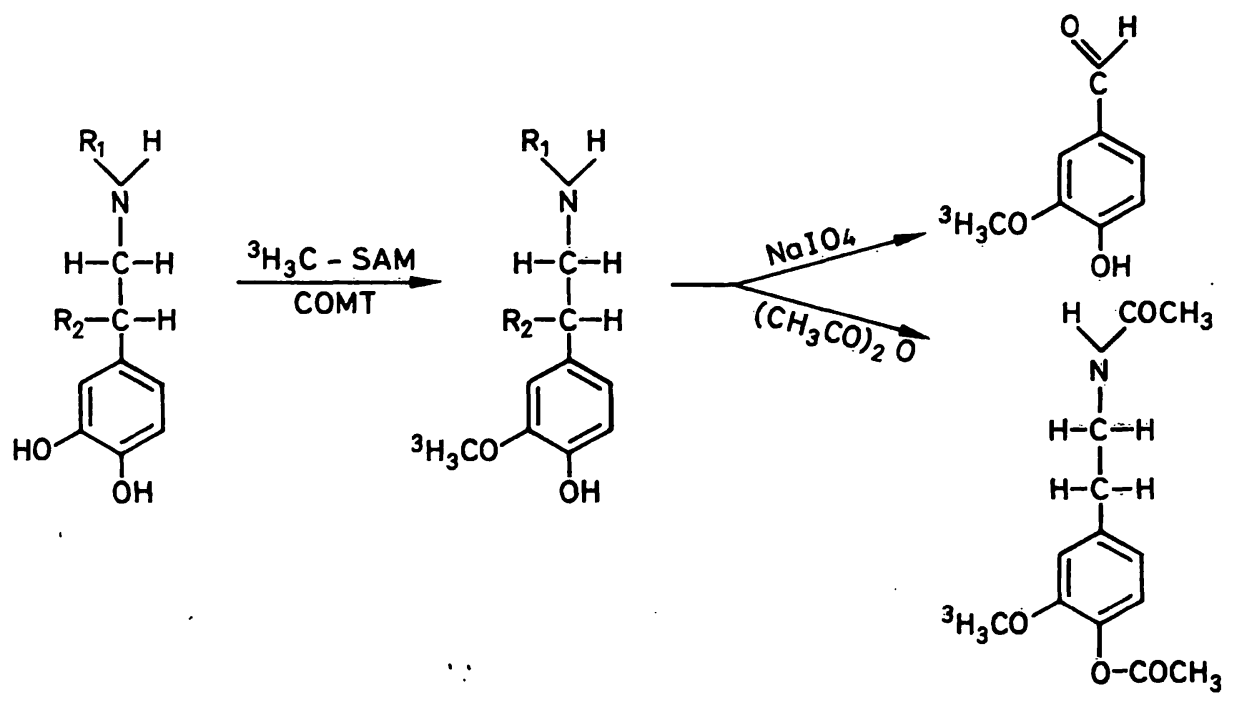

Fig. 1. Schematic representation of the major steps of the radioenzymatic cătecholamine assay.

SAM $=S$-adenosyl- $L$-methionine COMT = catechol-O-methyltransferase.
Norepinephrine: $\mathbf{R}_{1}=\mathbf{H}$

$\begin{array}{ll} & \mathbf{R}_{\mathbf{2}}=\mathrm{OH} \\ \text { Dopamine: } & \mathbf{R}_{\mathbf{1}}, \mathbf{R}_{\mathbf{2}}=\mathbf{H}\end{array}$

Epinephrine: $\quad \mathbf{R}_{1}=\mathrm{CH}_{3}$

$\mathbf{R}_{2}=\mathrm{OH}$ 
dopamine hydrochloride: Serva, Heidelberg, FRG; 2-(4'-tert.butylphenyl)-5-(4"-biphenyl)-1,2,3-oxadiazole (butyl-PBD) (4 g/l toluene), Riasolve I: Zinsser, Frankfurt/M., FRG; $\left[7-{ }^{3} \mathrm{H}(\mathrm{N})\right] D L$-normetanephrine (specific activity $0.48 \mathrm{TBq} /$ $\mathrm{mmol}=13 \mathrm{Ci} / \mathrm{mmol}),\left[7-{ }^{3} \mathrm{H}(\mathrm{N})\right] D L$-metanephrine (specific activity $0.34 \mathrm{TBq} / \mathrm{mmol}=9.3 \mathrm{Ci} / \mathrm{mmol}),\left[5-{ }^{3} \mathrm{H}(\mathrm{N})\right] 3-$ methoxytyramine (specific activity $0.41 \mathrm{TBq} / \mathrm{mmol}=11 \mathrm{Ci} / \mathrm{mmol}$ ), $S$-adenosyl- $L$-methionine (methyl $\left[{ }^{3} \mathrm{H}\right]$ ) (specific activity 2.04-3.15 TBq $/ \mathrm{mmol}=55-85 \mathrm{Ci} / \mathrm{mmol}):$ NEN, Dreieich, FRG. All other reagents used were of analytical grade and obtained from Merck (Darmstadt) or Riedel de Haen (Hannover, FRG). $2.5 \mathrm{~g} / 1 \mathrm{EGTA}$ and $2.5 \mathrm{~g} / 1 \mathrm{MgCl}_{2} \cdot 6 \mathrm{H}_{2} \mathrm{O}$ in $0.6 \mathrm{~mol} / 1$ perchloric acid (solution was prepared immediately before use). All other solutions were renewed every $2-3$ weeks. Kieselgel $60 \mathrm{~F}_{254}$ plates ( $250 \mu \mathrm{m}$ thickness, $5 \times 10 \mathrm{~cm}$, Merck) were used for thin-layer chromatography.

Solvent system: Chloroform/methanol/ethylamine $70 \%$ $(80 \mathrm{ml} / 15 \mathrm{ml} / 10 \mathrm{ml})$.

\section{Standard solutions}

Stock solutions: $5 \mathrm{mg}$ catecholamine (free base) in $20 \mathrm{ml}$ $0.01 \mathrm{~mol} / 1 \mathrm{HCl}$. These solutions are stored at $4{ }^{\circ} \mathrm{C}$. The working solutions are prepared by dilution of the stock solutions with $0.01 \mathrm{~mol} / 1 \mathrm{HCl}$; e.g. a 1:125000 dilution of the stock solution $(12.5 \mu \mathrm{g} / 50 \mu \mathrm{l})$ results in a working solution with a catecholamine-concentration of $100 \mathrm{pg} /$ $50 \mu 1$.

\section{Sample collection}

$6 \mathrm{mg}$ glutathione $(1.5 \mathrm{mg} / \mathrm{ml})$ were added in $4 \mathrm{ml}$ Monovettes ${ }^{\circledR}$ (Sarstedt, Nümbrecht-Rommelsdorf, FRG) and stored at $4{ }^{\circ} \mathrm{C}$. $100 \mu 1$ Liquemin ${ }^{\circledR}$ (500 USP-U sodium heparin, Hoffmann La Roche, Switzerland) are added shortly before blood sampling. Blood samples were obtained from cubital veins of supine patients. The Monovettes ${ }^{\circledR}$ were placed on ice immediately after collection and centrifuged within $10 \mathrm{~min}$ at $4{ }^{\circ} \mathrm{C}$ for $15 \mathrm{~min}$. Plasma was separated from the ery throcy tes as quickly as possible and deproteinized with an equal volume of $0.6 \mathrm{~mol} / 1$ perchloric acid containing EGTA $(2.5 \mathrm{~g} / \mathrm{l})$ and $\mathrm{MgCl}_{2} \times 6 \mathrm{H}_{2} \mathrm{O}(2.5 \mathrm{~g} / \mathrm{l})$. After centrifugation for $15 \mathrm{~min}$ at $4{ }^{\circ} \mathrm{C}$ the supernatant was directly used for the catecholamine determination or stored at $-27^{\circ} \mathrm{C}$ until analysis. The essential steps of the assay are summarized in figure 2.

$100 \mu$ of the supernatant (corresponding to $50 \mu$ l plasma) or $100 \mu l 0.3 \mathrm{~mol} / 1$ perchloric acid (assay of pure aqueous solutions) are pipetted in conical glass tubes, prechilled in an icewater bath. This is followed by $50 \mu \mathrm{l}$ standard working solution (samples with internal standard) or $50 \mu \mathrm{l} 0.01 \mathrm{~mol} / 1 \mathrm{HCl}$ (samples without internal standard and blanks). The reaction is started by the addition of the following mixture: $0.1 \mathrm{mg}$ dithiothreitol in $50 \mu \mathrm{l} 2 \mathrm{~mol} / 1$ tris-HCl buffer, $20 \mu \mathrm{l} 25 \mathrm{mmol} / \mathrm{l}$ $\mathrm{MgCl}_{2} \times 6 \mathrm{H}_{2} \mathrm{O},(92,5 \mathrm{kBq}=2.5 \mu \mathrm{Ci}) \mathrm{S}$-adenosyl- $L$-methionine (methyl[ $\left.\left.{ }^{3} \mathrm{H}\right]\right)(5 \mu 1 ; 30-45 \mathrm{pmol})$ and $25 \mu \mathrm{l}$ of the catechol-Omethyl-transferase preparation. (This solution is prepared in an ice-cold bath just before use and is shaken carefully, avoiding foaming). Dithiothreitol should be weighed out with a plastic or glass spatula because the thiol-groups react with heavy metals. The tubes are closed, then mixed thoroughly (Vortex) and incubated for $60 \mathrm{~min}$ at $37^{\circ} \mathrm{C}$ in a shaking water bath. The reaction mix ture has a pH of 8.15-8.20. After incubation the tubes are placed back into the ice-bath and the reaction is stopped by addition of $200 \mu \mathrm{l}$ of a mixture of $1 \mathrm{~mol} / 1$ borate buffer pH 8 and of a carrier solution (3/1 $\mathrm{v} / \mathrm{v}$ ). The carrieer solution contains $0.5 \mathrm{~g} / 10.01 \mathrm{~mol} / 1 \mathrm{HCl}$ of the cold methylated derivatives of the catecholamines (metanephrine, normetanephrine and 3-methoxytyramine). The mix ture of the borate buffer and the carrier solution is prepared freshly before use. After addition of $50 \mu l$ sodium tetraphenyl-borate solution $(15 \mathrm{~g} / \mathrm{l})$, the solution is mixed gently with a Vortex and then extracted with $10 \mathrm{ml}$ cold watersaturated diethyl ether by rotating the tubes for $10 \mathrm{~min}$. The phases are separated by low-speed centrifugation ( $3 \mathrm{~min}$ ). Now the tubes are quick-frozen, five at a time, in an acetone-dry ice bath for 30-60 s. The aqueous phase must be completely frozen. It is important that the aqueous layer is completely

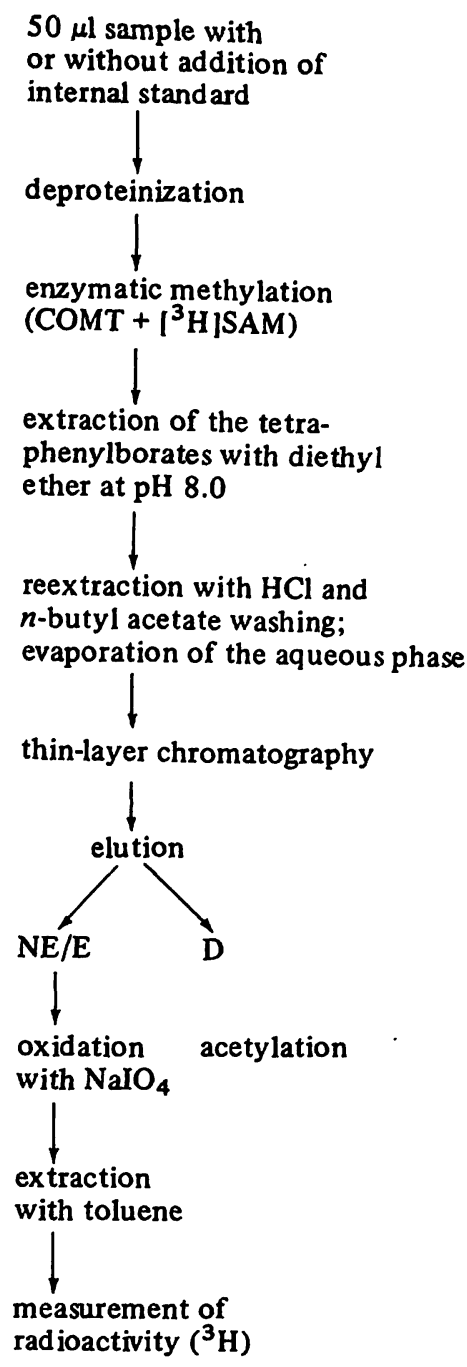

Fig. 2. Schematic representation of the working procedure of the radioenzymatic catecholamine assay.

submerged in the acetone-dry ice bath and that the organic layer is above the level of the bath. If the tubes are left in the bath too long, the water dissolved in the diethyl ether may also freeze (cloudiness). This results in a large deviation of the analyses. The diethyl ether is decanted into a set of new tubes containing $0.5 \mathrm{ml} 0.1 \mathrm{mmol} / 1 \mathrm{HCl}$. These tubes are again rotated for $10 \mathrm{~min}$, centrifuged and quick-frozen. The organic layer is discarded and the frozen aqueous phase is washed with $2 \mathrm{ml}$ diethyl ether. The hydrochloric acid phase is then thawed, $5 \mathrm{ml}$ water saturated $n$-butyl-acetate are added and mixed vigorously with a Vortex mixer for $30 \mathrm{~s}$. The phases are separated by low-speed centrifugation and the organic phase is aspirated and discarded. The $n$-butyl acetate washing is repeated. The aqueous phases are evaporated to dryness, 6 samples at a time, under high vacuum in a rotary evaporator in a water bath at $20^{\circ} \mathrm{C}$.

The residue is taken up with $100 \mu \mathrm{l}$ of a mixture of methanol and $0.01 \mathrm{~mol} / 1 \mathrm{HCl}(5: 1 \mathrm{v} / \mathrm{v})$ containing $1 \mu 1 \beta$-mercaptoethanol per $\mathrm{ml}$ as an antioxidant. This solution is spotted on a Kieselgel $60 \mathrm{~F}_{254}$ plate in a band approximately $0.5 \times 3 \mathrm{~cm}$ under a stream of cold air. The chromatogram is developed for $25-30 \mathrm{~min}$ in a mixture of chloroform $/ \mathrm{methanol} / \mathrm{ethyl}$ amine $70 \%(16 \mathrm{ml} / 3 \mathrm{ml} / 2 \mathrm{ml})$. The plates are dried thoroughly under a stream of cold air and the bands are localized under UV light $(254 \mathrm{~nm})$. The silica gel of the three spots corresponding to metanephrine, normetanephrine and 3-methoxy ty ramine are scraped off into Eppendorf tubes. $1.3 \mathrm{ml}$ of $2 \mathrm{~mol} / \mathrm{l}$ $\mathrm{NH}_{3}$ solution is added to the tubes corresponding to metanephrine and normetanephrine, followed by shaking for $10 \mathrm{~min}$ 
to elute the methylated catecholamines. After centrifuging for 2 min with the Eppendorf-centrifuge $(15000 \mathrm{~g}) 1 \mathrm{ml}$ of the supernatant is transferred to new glass-stoppered tubes. The precipitate is resuspended in $0.5 \mathrm{ml} 2 \mathrm{~mol} / 1 \mathrm{NH}_{3}$ solution and after shaking for $5 \mathrm{~min}$ and centrifuging for $2 \mathrm{~min} 0.6 \mathrm{ml}$ of the supernatant are combined with the first $\mathrm{NH}_{3}$ eluate. 3-Methoxytyramine is eluted with $0.01 \mathrm{~mol} / 1 \mathrm{HCl}$ in the same way as described for metanephrine and normetanephrine.

$100 \mu \mathrm{l}$ of a $40 \mathrm{~g} / \mathrm{l} \mathrm{NaIO}_{4}$-solution are added to the tubes with the metanephrine and normetanephrine eluates. After mixing with a Vortex mixer the tubes are shaken gently for $10 \mathrm{~min}$ at room temperature. The reaction is stopped in an ice-cold bath after $10 \mathrm{~min}$ by the addition of $400 \mu \mathrm{l}$ of $10 \mathrm{~mol} / 1$ acetic acid $(\mathrm{pH} 6)$. The tubes are again shaken for a short time and then $10 \mathrm{ml}$ toluene are added to each tube. The vanillin, formed by metaperiodate oxidation of metanephrine and normetanephrine is extracted into toluene by shaking the tubes for $10 \mathrm{~min}$ on a mechanical shaker. The phases are separated by low-speed centrifugation for $3 \mathrm{~min}$ and quick-freezing of the lower aqueous phase. The toluene phase is decanted in polyethylene counting vials, being prefilled with $5 \mathrm{ml}$ of butyl-PBD-toluene scintillation fluid. The vials are capped, shaken vigorously and counted in a liquid scintillation spectrometer (Mark II, Searle Anal.) for 10 $\mathrm{min}$. The counting efficiency is $57-59 \%$.

The 3-methoxytyramine eluate is acetylated at room temperature by Vortex-mixing for $30 \mathrm{~s}$ with $0.16 \mathrm{~g}$ sodium bicarbonate and $200 \mu \mathrm{l}$ of acetic anhydride. After exactly $5 \mathrm{~min}$ the excess sodium bicarbonate is neutralized with glacial acetic acid. The solutions are allowed to stand for $\mathbf{3 0} \mathrm{min}$ to ensure the hydrolysis of the excess acetic anhydride. Subsequent treatment of the samples is as described for metanephrine and normetanephrine after the periodate oxidation.

\section{Calculation}

The quantitative evaluation of the samples is based upon the radioactivity of the internal standard.

$$
\begin{aligned}
& \frac{\mathrm{cpm}_{\text {sample }}-\mathrm{cpm}_{\text {blank }}}{\left.\mathrm{cpm}_{\text {(sample }}+\text { standard }\right)-\mathrm{cpm}_{\text {sample }}} \times \frac{\mathrm{pg}_{\text {standard }}}{\mathrm{ml} \text { sample }}= \\
& \frac{\mathrm{pg}_{\text {catecholamine }}}{\mathrm{ml}_{\text {sample }}}= \\
& \mathrm{ng} / \mathrm{l} \text { catecholamine in the sample }
\end{aligned}
$$

\section{Results and Discussion}

\section{Enzymatic methylation}

First, the optimal conditions of the different steps of the enzymatic methylation were determined. We investigated the dependence of the yield of normetanephrine on the concentrations of S-adenosyl-methionine, norepinephrine, and $\mathrm{Ca}^{2+}$, on the quantity of catechol0 -methyl-transferase and the reaction time. Pure aqueous solutions of norepinephrine were used for these investigations. These measurements were performed fluorimetrically with cold S-adenosyl- $L$ methionine according to Axelrod \& Tomchick i4, 15). As a result of these investigations $0.5 \mathrm{mg}$ catecholO-methyltransferase (referring to the protein content), a reaction time of $60 \mathrm{~min}$ and a 10 fold excess of $S$ adenosyl- $L$-methionine (in relation to the substrate norepinephrine) were necessary for an optimal methylating reaction. $60 \mathrm{nmol}$ of norepinephrine were used for these measurements. The efficiency of the enzymatic

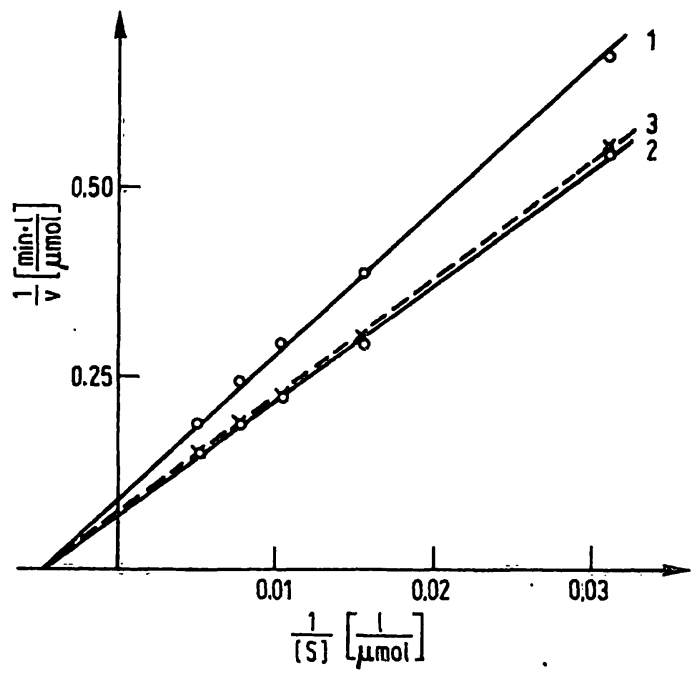

Fig. 3. Inhibition of the enzyme reaction of norepinephrine after addition of $\mathrm{Ca}^{2+}$ (curve 1) and removal of the inhibition by the addition of EGTA (curve 2). Curve 3 demonstrates the enzymatic reaction of norepinephrine in the presence of EGTA but without $\mathrm{Ca}^{2+}$.

methylation was $80 \%$. With the radioenzymatic examination of this reaction we got lower recoveries for norepinephrine $(70 \%)$ and dopamine $(55 \%)$ and a similar recovery for epinephrine ( $85 \%)$. Figure 3 demonstràtes the inhibition on the methylation by $\mathrm{Ca}^{2+}$ and its removal by addition of the $\mathrm{Ca}^{2+}$ chelating agent EGTA.

Curve 1 shows the inhibition by $\mathrm{Ca}^{2+}$ of the enzyme reaction $\left(0.26 \mu \mathrm{mol} \mathrm{Ca}{ }^{2+}\right)$. Using $50 \mu \mathrm{l}$ of plasma as starting volume, $0.26 \mu \mathrm{mol} \mathrm{Ca}{ }^{2+}$ are equivalent to the upper limit of the normal range of calcium in plasma. Curve 2 shows the prevention of the inhibitory effect of $\mathrm{Ca}^{2+}$ by the addition of $0.52 \mu \mathrm{mol}$ of EGTA and curve 3 demonstrates the course of reaction in the presence of EGTA but without $\mathrm{Ca}^{2+}$. These investigations prove that the inhibition of catechol-0-methyltransferase by $\mathrm{Ca}^{2+}$ is completely removed by addition of EGTA.

\section{Purification of the 3-methoxy-derivatives}

Oxidation of the metanephrines with sodium metaperiodate or acetylation of 3-methoxytyramine with acetic anhydride are important steps after the thinlayer chromatographic separation of the 3-methoxy derivatives. The additional purificaton steps result in a considerable reduction of the blanks.

Da Prada \& Zürcher (6) oxidized the metanephrines in $2 \mathrm{~mol} / 1 \mathrm{NH}_{3}$ (about $1.8 \mathrm{ml}$ eluate) with $0.25 \mathrm{ml}$ of $30 \mathrm{~g} / 1$ sodium metaperiodate solution for $10 \mathrm{~min}$ at $37^{\circ} \mathrm{C}$. These authors reported recoveries of 86 and $73 \%$ for metanephrine and normetanephrine resp. We found recoveries of $73 \pm 2 \%$ for both compounds. Our attempts to enhance the recovery by variation of the reaction conditions (volume of oxidant and extraction agent or reaction temperature) resulted in no significant improvement. 
In contrast to da Prada \& Zürcher, who directly measured the radioactivity of the 3-methoxytyramine eluate after thin-layer chromatography, and in accordance with some other authors $(16,17)$, we introduced the acetylation of 3-methoxytyramine as an additional purification step. This results in an improvement of the counting efficiency (from $22 \%$ to $57 \%$ ) and in a reduction of the blanks.

\section{Blanks}

As mentioned previously we intended to increase the sensitivity of the method by use of S-adenosyl- $L$ methionine (methyl $\left.\left[{ }^{3} \mathrm{H}\right]\right)$ with a very high specific activity $(2.04-3.15 \mathrm{TBq} / \mathrm{mmol}=55-85 \mathrm{Ci} / \mathrm{mmol})$. However, this introduced problems regarding the blanks. They showed great inter-assay variability, though we used the same solutions and $S$-adenosyl- $L$-methionine(methyl[ $\left.{ }^{3} \mathrm{H}\right]$ ) of the same lot. Therefore we ran 3 different blanks in one assay:

1. Plasma oxidized with sodium metaperiodate $(2 \mathrm{mg}$ / $\mathrm{ml}$ ) for $10 \mathrm{~min}$ at $37^{\circ} \mathrm{C}$ and subsequently deproteinized with perchloric acid $(0.6 \mathrm{~mol} / 1)$.

2. The complete incubation mixture without the catecholO-methyl-transferase is added to the deproteinized plasma (the enzyme is replaced by an albumin solution with the same protein concentration).

3. Plasma, which had been allowed to stand for 14 days at room temperature.

The efficiency of the various isolation steps was examined by measuring the radioactivity of aliquots after the extractions. The results of these measurements are summarized in table 1; they are expressed in $\mathrm{dpm}(\mathrm{Bq})$ to eliminate variable quench effects.

As can be seen from this table, the greatest differences occur at the first separation steps, the extraction of the tetraphenylborates with diethyl ether. The high blank 3 is possibly caused by the slower decomposition of the catecholamines bound to plasma proteins.

An additional washing of the diethyl ether phase with $0.1 \mathrm{~mol} / 1$ borate buffer, or a second washing of the $\mathrm{HCl}$ phase with butyl acetate, or the application of different developing solutions brought no further reduction of the blanks. Table 2 illustrates the variouis solvent systems which were tested, the $\mathbf{R}_{\mathbf{f}}$-values of the methylated catecholamines and the development times.

Due to the short time required for development and the good separation, solvent system 1 was used for subsequent investigations. From the 3 blanks tested, we chose blank 1 for our experiments.

\section{Losses at various separation steps}

The radioenzymatic determination of the catecholamines consists of a series of separation steps as seen in figure 2 . The losses at the different steps were determined by
Tab. 1. Gradual reduction of 4 different blank values throughout various separation steps. Blanks 1,2 and 3 refer to the 3 blanks described in the text. The initial radioactivity was $92.5 \mathrm{kBq}=2.5 \mu \mathrm{Ci}$. The results are given in $\mathrm{min}^{-1}$ and $\mathrm{s}^{-1}(\mathrm{~Bq})$ !

\begin{tabular}{|c|c|c|c|c|}
\hline$\cdot$ & $\begin{array}{l}1 \\
\min _{(B q}-1\end{array}$ & $\begin{array}{l}2 \\
\min _{(B q}-1\end{array}$ & $\begin{array}{l}3 \\
\min ^{-1} \\
(B q)\end{array}$ & $\begin{array}{l}\left.4^{+}\right) \\
\min _{(\mathrm{Bq}}^{-1}\end{array}$ \\
\hline $\begin{array}{l}\text { Diethyl ether } \\
\text { extraction }\end{array}$ & $\begin{array}{r}52923 \\
(882)\end{array}$ & $\begin{array}{r}58520 \\
(975)\end{array}$ & $\begin{array}{r}290688 \\
(4845)\end{array}$ & $\begin{array}{r}183547 \\
(3059)\end{array}$ \\
\hline $\mathrm{HCl}$-extraction & $\begin{array}{r}13225 \\
(220)\end{array}$ & $\begin{array}{r}22359 \\
(373)\end{array}$ & $\begin{array}{r}44352 \\
(739)\end{array}$ & $\begin{array}{r}44397 \\
(740)\end{array}$ \\
\hline $\begin{array}{l}\text { 1. } n \text {-butyl acetate } \\
\text { washing }\end{array}$ & $\begin{array}{r}10312 \\
(172)\end{array}$ & $\begin{array}{r}19276 \\
(321)\end{array}$ & $\begin{array}{r}30150 \\
(503)\end{array}$ & $\begin{array}{r}32720 \\
(545)\end{array}$ \\
\hline $\begin{array}{l}\text { 2. } n \text {-butyl acetate } \\
\text { washing }\end{array}$ & $\begin{array}{l}9097 \\
(152)\end{array}$ & $\begin{array}{r}17657 \\
(294)\end{array}$ & $\begin{array}{r}24031 \\
(401)\end{array}$ & - \\
\hline \multicolumn{5}{|l|}{ Elution from silica gel } \\
\hline Normetanephrine & $\begin{array}{r}1488 \\
(24.8)\end{array}$ & $\begin{array}{r}2716 \\
(45.3)\end{array}$ & $\begin{array}{r}2351 \\
(39.2)\end{array}$ & $\begin{array}{r}364 \\
(6.1)\end{array}$ \\
\hline Metanephrine & $\begin{array}{r}1142 \\
(19.0)\end{array}$ & $\begin{array}{r}1674 \\
(27.9)\end{array}$ & $\begin{array}{r}2267 \\
(37.8)\end{array}$ & $\begin{array}{r}205 \\
(3.4)\end{array}$ \\
\hline 3-Methoxytyramine & $\begin{array}{r}571 \\
(9.5)\end{array}$ & $\begin{array}{r}744 \\
(12.4)\end{array}$ & $\begin{array}{r}927 \\
(15.5)\end{array}$ & $\begin{array}{r}612 \\
(10.2)\end{array}$ \\
\hline \multicolumn{5}{|l|}{$\begin{array}{l}\text { After oxidation or } \\
\text { acetylation }\end{array}$} \\
\hline Normetanephrine & $\begin{array}{r}30 \\
(0.50)\end{array}$ & $\begin{array}{r}43 \\
(0.72)\end{array}$ & $\begin{array}{r}183 \\
(3.05)\end{array}$ & $\begin{array}{r}43 \\
(0.72)\end{array}$ \\
\hline Metanephrine & $\begin{array}{r}28 \\
(0.47)\end{array}$ & $\begin{array}{r}27 \\
(0.45)\end{array}$ & $\begin{array}{r}216 \\
(3.60)\end{array}$ & $\begin{array}{r}45 \\
(0.75)\end{array}$ \\
\hline 3-Methoxy tyramine & $\begin{array}{r}40 \\
(0.67)\end{array}$ & $\begin{array}{r}47 \\
(0.78)\end{array}$ & $\begin{array}{r}228 \\
(3.80)\end{array}$ & - \\
\hline
\end{tabular}

+) according to da Prada \& Zürcher.

Tab. 2. $R_{\mathrm{f}}$-values of the methylated catecholamine derivatives and development times of the 3 solvent systems tested:

Solvent system 1: Chloroform:methanol:ethylamine $70 \%(80 \mathrm{ml} / 15 \mathrm{ml} / 10 \mathrm{ml})$

Solvent system 2: tert.-amylalcohol:benzene:methylamine $40 \%(60 \mathrm{ml} / 20 \mathrm{ml} / 30 \mathrm{ml})$

Solvent system 3: sec.-amylalcohol:benzene:chloroform: me thanol:ethylamine $(60 \mathrm{ml} / 20 \mathrm{ml} / 25 \mathrm{ml} / 40 \mathrm{ml} / 7.5 \mathrm{ml})$

\begin{tabular}{lllll}
\multicolumn{5}{c}{ RFValues $^{\text {Solvent }}$} \\
System & $\begin{array}{l}\text { Normetan- } \\
\text { ephrine }\end{array}$ & $\begin{array}{l}\text { Metan- } \\
\text { ephrine }\end{array}$ & $\begin{array}{l}\text { 3-Methoxy- } \\
\text { tyramine }\end{array}$ & $\begin{array}{l}\text { Develop- } \\
\text { ment time } \\
\text { (min) }\end{array}$ \\
\hline 1 & 0.29 & 0.42 & 0.61 & 24 \\
2 & 0.18 & 0.27 & 0.37 & 55 \\
3 & 0.38 & 0.49 & 0.63 & 35 \\
\hline
\end{tabular}

measuring the recoveries of $\left[{ }^{3} \mathrm{H}\right]$ metanephrine, $\left[{ }^{3} \mathrm{H}\right]$ normetanephrine and $\left[{ }^{3} \mathrm{H}\right] 3$-methoxytyramine in percent of the initial radioactivity. The results are shown in table 3.

The results are the mean of 3 determinations. As can be seen from this table the greatest losses occur during thinlayer chromatography and subsequent elution of the methylated derivatives from the silica gel. 
Tab. 3. Recoveries of $\left[{ }^{3} \mathrm{H}\right]$ normetanephrine, $\left[{ }^{3} \mathrm{H}\right]$ metanephrine and $\left[{ }^{3} \mathrm{H}\right]$ methoxy tyramine at various separation steps. The recoveries of the three compounds were determined individually.

\begin{tabular}{llll}
\hline $\begin{array}{l}\text { Separation } \\
\text { steps }\end{array}$ & $\begin{array}{l}\text { Recovery (\%) } \\
{\left[{ }^{3} \mathrm{H}\right] \text { Norm- }} \\
\text { etanephrine }\end{array}$ & $\begin{array}{l}{\left[{ }^{3} \mathrm{H}\right] \mathrm{Metan}-} \\
\text { ephrine }\end{array}$ & $\begin{array}{l}{\left[{ }^{3} \mathrm{H}\right] \text { Methoxy- }} \\
\text { tyramine }\end{array}$ \\
\hline $\begin{array}{l}\text { Diethyl ether } \\
\text { extraction }\end{array}$ & $75.1 \pm 2.8$ & $79.5 \pm 1.6$ & $82.4 \pm 3.8$ \\
$\begin{array}{l}\text { 0.1 mol/1 HCl- } \\
\text { extraction }\end{array}$ & $74.7 \pm 1.7$ & $78.0 \pm 0.8$ & $77.5 \pm 4.2$ \\
$\begin{array}{l}n \text {-butyl acetate } \\
\text { washing }\end{array}$ & $73.5 \pm 2.1$ & $76.7 \pm 0.7$ & $75.9 \pm 1.7$ \\
$\begin{array}{l}\text { Elution from } \\
\text { silica gel }\end{array}$ & $44.8 \pm 0.9$ & $48.5 \pm 1.3$ & $53.9 \pm 3.5$ \\
$\begin{array}{l}\text { Oxidation or } \\
\text { acetylation and } \\
\text { toluene extrac- } \\
\text { tion }\end{array}$ & $33.6 \pm 1.2$ & $36.4 \pm 1.9$ & $40.4 \pm 3.3$ \\
\hline
\end{tabular}

Reliability criteria of the method

\section{Intra-assay variability}

A human plasma pool was used for the determination of the intra-assay variability. $10 \mathrm{pg}$ norepinephrine, $3 \mathrm{pg}$ epinephrine and $3 \mathrm{pg}$ dopamine were added per $50 \mu \mathrm{l}$ of plasma. Seven samples were analyzed in one run. The results are depicted in table 4.

Variation coefficients between 3.4 and $8.6 \%$ were found for the intra-assay variability.

\section{Accuracy}

The linearity of the assay was examined with aqueous solutions of the catecholamines and plasma samples. Figu re 4 shows the measured values of the plasma with different additions of known amounts of catecholamines.

Each value is the mean of 3 determinations. As can be seen from figure 4 the assay is linear in the range from $0-100 \mathrm{pg}$. Measurements on aqueous solutions of catecholamines also revealed a linear relationship

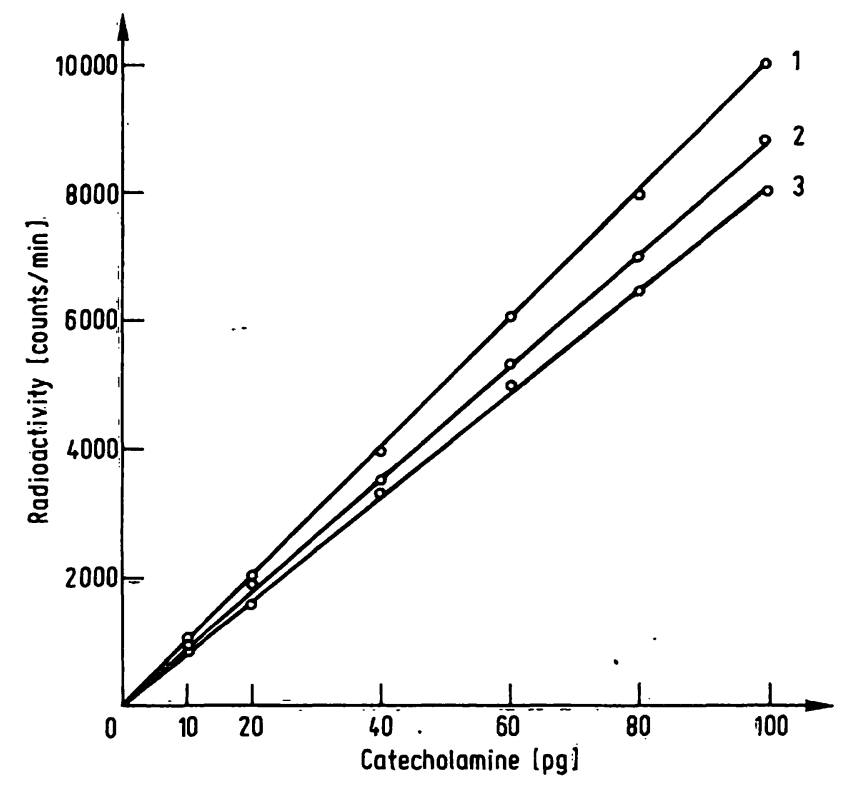

Fig. 4. Relationship between the measured radioactivity and the starting quantities of the catecholamines.

1. Epinephrine 2. Dopamine 3. Norepinephrine.

between the counts/min and the concentration up to $150 \mathrm{pg}$. Recovery experiments with different additions of catecholamines to a plasma pool were also carried out. If the calculation was based on a standard curve measured some days before, the recoveries ranged from $103-130 \%$. The greatest deviations occurred with dopamine. If the calculation was based on the radioactivity of the internal standards, we obtained recoveries between 88 and $93 \%$.

\section{Detection limit}

The detection limit can be calculated from the threefold standard deviation of the blanks (18). We determined it by running 10 blanks in one series.

As shown in table 5 the detection limit for norepinephrine is $12 \mathrm{ng} / \mathrm{l}$, for dopamine $6 \mathrm{ng} / \mathrm{l}$ and for epinephrine $3 \mathrm{ng} / 1$. Other authors (12) defined the detection limit as a sample-to-blank ratio of 2 . Table 6 shows a comparison between some radioenzymatic catecholamine-assays published recently, with special reference to the sensitivity.

Tab. 4. Intra-assay variability $(n=7)$.

\begin{tabular}{|c|c|c|c|c|c|c|}
\hline \multirow[b]{2}{*}{$\therefore$} & \multirow{2}{*}{$\begin{array}{l}\text { Blank } \\
\bar{x} \\
\text { (counts/ } \\
\text { min) }\end{array}$} & \multicolumn{5}{|l|}{ Sample' } \\
\hline & & $\begin{array}{l}\overline{\mathbf{x}} \\
\text { (counts/. } \\
\text { min) }\end{array}$ & $\begin{array}{l}\text { s } \\
\text { (counts/ } \\
\text { min) }\end{array}$ & $\begin{array}{l}\overline{\bar{x}} \\
\text { (counts/ } \\
\min \cdot p g)\end{array}$ & $\begin{array}{l}\text { s } \\
\text { (counts/ } \\
\min \cdot p g \text { ) }\end{array}$ & VK (\%) \\
\hline $10 \mathrm{pg}$ Norepinephrine & 199 & 996 & 27 & 79.9 & 2.7 & 3.4 \\
\hline 3 pg Epinephrine & 142 & 454 & 18 & 104.0 & 6.0 & 5.8 \\
\hline 3 pg Dopamine & 343 & 611 & 23 & 89.3 & 7.9 & 8.6 \\
\hline
\end{tabular}


Tab. 5. Detection limit of the assay.

(Calculation based upon the intra-assay variability of the blanks (18))

\begin{tabular}{|c|c|c|c|c|c|c|c|}
\hline \multirow{2}{*}{ Compound } & \multicolumn{3}{|c|}{ Blanks (counts/min) } & \multirow{2}{*}{$3 s$} & \multirow{2}{*}{$\begin{array}{l}\bar{x} \\
\text { (counts/ } \\
\min \cdot p g)\end{array}$} & \multicolumn{2}{|c|}{ Detection limit } \\
\hline & $\mathbf{x}$ & \pm & $\mathbf{s}$ & & & $\mathrm{pg} / 50 \mu \mathrm{l}$ & $\mathrm{ng} / 1$ \\
\hline Norepinephrine & 266 & \pm & 16.7 & 50.1 & 77 & 0.61 & 12.2 \\
\hline Epinephrine & 155 & \pm & 5.8 & 17.4 & 98 & 0.18 & 3.6 \\
\hline Dopamine & 163 & \pm & 10.3 & 31.0 & 90 & 0.32 & 6.4 \\
\hline
\end{tabular}

Tab. 6. Sensitivity of the radioenzymatic determination of catecholamines as reported by various authors.

\begin{tabular}{|c|c|c|c|c|c|c|}
\hline & $\begin{array}{l}\text { Engelman } \\
\text { et al. (1970) }\end{array}$ & $\begin{array}{l}\text { Passon } \\
\text { \& Peuler } \\
(1973)\end{array}$ & $\begin{array}{l}\text { Da Prada } \\
\text { \& Zürcher } \\
(1976)\end{array}$ & $\begin{array}{l}\text { Peuler } \\
\text { \& Johnson } \\
\text { (1977) }\end{array}$ & $\begin{array}{l}\text { Saller } \\
\text { \& Zigmond } \\
(1978)\end{array}$ & $\begin{array}{l}\text { Bosak et al. } \\
(1980)\end{array}$ \\
\hline $\begin{array}{l}\text { counts } / \mathrm{min} \cdot \mathrm{ng} \\
\text { Norepinephrine } \\
\quad \text { (counts/min blanks) }\end{array}$ & $\begin{array}{l}42 \\
(11)\end{array}$ & $\begin{array}{l}438 \\
(10)\end{array}$ & $\begin{array}{c}28973 / 29000 \\
(18)\end{array}$ & $\begin{array}{c}33000 \\
(26)\end{array}$ & $\begin{array}{c}61980 / 18200 \\
(525 / 52)\end{array}$ & $\begin{array}{l}79700 \\
(17)\end{array}$ \\
\hline $\begin{array}{l}\text { counts/min } \cdot \mathrm{ng} \\
\text { Epinephrine } \\
\text { (counts/min blanks) }\end{array}$ & $\begin{array}{l}44 \\
(11)\end{array}$ & $\begin{array}{l}767 \\
(10)\end{array}$ & $\begin{array}{c}28502 / 35000 \\
(18)\end{array}$ & $\begin{array}{l}39000 \\
(33)\end{array}$ & $\begin{array}{c}61108 / 16152 \\
(694 / 56)\end{array}$ & $\begin{array}{r}104000 \\
(16)\end{array}$ \\
\hline $\begin{array}{l}\text { counts/min } \cdot \mathrm{ng} \\
\text { Dopamine } \\
\text { (counts/min blanks) }\end{array}$ & $\cdot-$ & - & $\begin{array}{c}21677 / 19000 \\
(32)\end{array}$ & $\begin{array}{l}33000 \\
(180)\end{array}$ & $\begin{array}{c}61416 / 19236 \\
(529 / 64)\end{array}$ & $\begin{array}{c}89300 \\
(23)\end{array}$ \\
\hline $\begin{array}{l}\text { Specific activity } \\
\text { of S-adenosyl- } \\
\left.L \text {-methionine(methyl }\left[{ }^{3} \mathrm{H}\right]\right) \\
(\mathrm{Ci} / \mathrm{mmol}) \\
(\mathrm{GBq} / \mathrm{mmol})\end{array}$ & $\begin{array}{c}0.048-0.055 \\
1.78-2.04\end{array}$ & $\begin{array}{r}4 \\
148\end{array}$ & $\begin{array}{c}7-10 \\
259-370\end{array}$ & $\begin{array}{c}9-11 \\
333-407\end{array}$ & $\begin{array}{r}80 \\
2960\end{array}$ & $\begin{array}{c}60-80 \\
2220-2960\end{array}$ \\
\hline $\begin{array}{l}\text { Detection limit } \\
\text { (pg) }\end{array}$ & 250 & $20 / 13$ & $0.6 / 0.6 / 1.5$ & $0.75 / 0.85 / 6.5$ & $\begin{array}{l}8.5 / 11.3 / 8.5 \\
(2.85 / 3.47 / 3.33)\end{array}$ & $0.20 / 0.15 / 0.26$ \\
\hline Sample volume $(\mu \mathrm{l})$ & 10000 & 500 & 50 & 50 & 10 & 50 \\
\hline $\begin{array}{l}\text { Detection limit } \\
\text { (ng/1) }\end{array}$ & 25 & $40 / 26$ & $12 / 12 / 30$ & $15 / 17 / 110$ & $\begin{array}{l}850 / 1130 / 850 \\
(285 / 347 / 333)\end{array}$ & $4 / 3 / 5$ \\
\hline
\end{tabular}

As can be seen from these values, the sensitivity of the assays increased with the availability of higher specific activity of $S$-adenosyl- $L$-methionine(methyl[ $\left.\left[{ }^{3} \mathbf{H}\right]\right)$. Moreover some authors report detection limits which are above the resting catecholamine concentrations in human plassma.

\section{Application of the assay}

\section{Resting plasma catecholamine concentrations}

Blood samples were taken from 4 volunteers, which had been recumbent for $30 \mathrm{~min}$. The following catecholamine concentrations were determined: epinephrine $26-85 \mathrm{ng} / \mathrm{l}$, norepinephrine $73-215 \mathrm{ng} / \mathrm{l}$ and dopamine 9-37 $\mathrm{ng} / \mathrm{l}$. These values are in agreement with those reported by other authors $(2,6,9)$.

\section{Stability of plasma catecholamines}

a) Sample collection

Blood was collected with $4 \mathrm{ml}$ Monovettes ${ }^{\circledR}$ (Sarstedt) containing per $\mathrm{ml}$ blood: $20 \mu \mathrm{L}$ Liquemin ${ }^{\circledR}$ and $20 \mu \mathrm{l}$ of a freshly prepared solution containing $144 \mathrm{mg}$ EGTA and $72 \mathrm{mg}$ reduced glutathione per $\mathrm{ml} \mathrm{H}_{2} \mathrm{O}$; the $\mathrm{pH}$ of this solution was adjusted to $6.4-7.0$ with $6 \mathrm{~mol} / 1 \mathrm{NaOH}$.

The Monovettes ${ }^{\circledR}$ were placed on ice immediately after blood collection and centrifuged within $10 \mathrm{~min}$ at $4{ }^{\circ} \mathrm{C}$. Plasma was dispensed in $300 \mu \mathrm{l}$-portions in disposable plastic containers (Eppendorf tubes) and stored under different conditions.

\section{b) Sample storage}

Plasma samples of two individuals were stored at $-70^{\circ} \mathrm{C}$, $-27^{\circ} \mathrm{C}$ and $+4{ }^{\circ} \mathrm{C}$ and the plasma of a third subject was stored at room temperature $\left(22^{\circ} \mathrm{C}\right)$. 

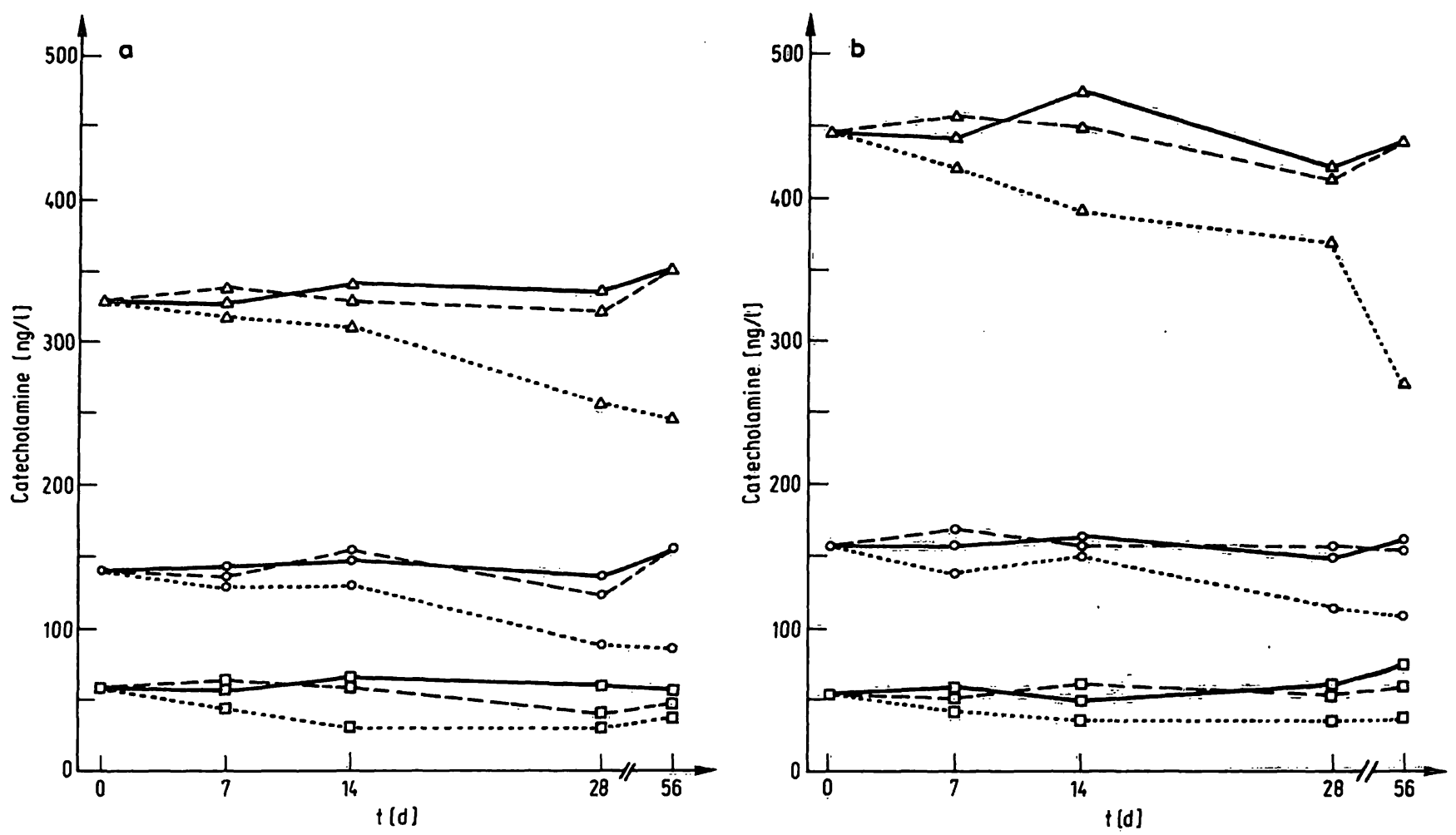

Figs. $5 \mathrm{a}$ and $\mathrm{b}$ : Stability of plasma catecholamines of two volunteers in dependence on duration and temperature of storage. ( 0 = epinephrine; $\Delta=$ norepinephrine; $\quad \square=$ dopamine; - stored at $-70^{\circ} \mathrm{C}-\ldots$ stored at $-27^{\circ} \mathrm{C}$ ..... stored at $+4{ }^{\circ} \mathrm{C}$ ).

c) Catecholamine determination

Plasma samples were thawed at room temperature and centrifuged with an Eppendorf portable centrifuge for $1 \mathrm{~min}$. All measurements were carried out in duplicate. The calculation was based on internal standards and $\mathrm{NaIO}_{4}$-oxidized plasma was used for the blanks.

Figures $5 \mathrm{a}$ and $5 \mathrm{~b}$ demonstrate that plasma catecholamines are remarkably stable when stored at $-70^{\circ} \mathrm{C}$ or at $-27^{\circ} \mathrm{C}$. There is no significant decrease in catecholamine concentration over a period of 8 weeks. Higher storage temperatures lead to a gradual decrease in plasma catecholamine concentrations. After two plasma samples had been stored at $+4{ }^{\circ} \mathrm{C}$ for 8 weeks, only $60(74) \%$ of the norepinephrine, $75(65) \%$ of the epinephrine and $65(60) \%$ of the dopamine were found, compared to the initial plasma concentrations immediately after blood sampling. Even if stored at room temperature plasma catecholamines only showed a slight decrease. As a result of these investigations it can be concluded that it is possible to store plasma samples at room temperature for some hours and at $-27^{\circ} \mathrm{C}$ for some weeks without losses in catecholamine content.

\section{Stability of catecholamines in blood}

$10 \mathrm{ml}$ blood were taken from three volunteers. The blood samples were mixed with the anticoagulant, divided into five parts and immediately placed on ice. Plasma of the first blood sample was separated by centrifugation directly after mixing. The other samples were centrifuged $15,30,45$ and $60 \mathrm{~min}$ resp. after venepuncture. Determination of epinephrine and norepinephrine revealed that there was no decay of catecholamine content over the period of study.

Our findings on the stability of catecholamines in blood and plasma are contrary to those of other authors (19), who established a quicker decay of plasma catecholamine content, using a fluorometric method. It may be that this difference is caused by the lower specificity of the fluorometric method in comparison to the radioenzymatic assay. 


\section{References}

1. Engelman, K., Portnoy, B. \& Lovenberg, W. (1968), Am. J. Med. Sci. 255, 259-268.

2. Engelman, K. \& Portnoy, B. (1970), Circ. Res. 26, 53-57.

3. Passon, P. G. \& Peuler, J. D. (1973), Anal. Biochem. 51, 618-631.

4. Coyle, J. T. \& Henry, D. P. (1973), J. Neurochem. 21, 61-67.

5. Henry, D. P., Starman, B. J., Johnson, D. G. \& Williams, R. H. (1975), Life Sci. 16, 375-384.

6. da Prada, M. \& Zürcher, G. (1976), Life Sci. 19, 1161 -1174 .

7. Weise, V. K. \& Kopin, I. J. (1976), Life Sci. 19, 1673-1686.

8. Cauchy, C., Tassin, J. P., Glowinsky, J. \& Cheramy, A. (1976), J. Neurochem. 26, 471-480.

9. Peuler, J. D. \& Johnson, G. A. (1977), Life Sci. 21 , 625-636.

10. Hörtnagl, H., Benedict, C. R. \& Grahame-Smith, D. G. (1977), Br. J. Clin. Pharmacol. 4, 553-558.
11. Johnson, G. A., Gren, J. M. \& Rupiecki, Rosemary (1978), Clin. Chem. 24, 1927-1930.

12. Saller, C. F. \& Zigmond, M. J. (1978), Life Sci. 23, 1117-1130.

13. Evans, M. I., Halter, J. B. \& Porte, D. (1978), Clin. Chem. 24, 567-570.

14. Axelrod, J. \& Tomchick, R. (1958), J. Biol. Chem. 223, 702-705.

15. Palkovits, M., Brownstein, M., Saavedra, J. M. \& Axelrod, J. (1974), Brain Res. 77, 137-149.

16. Klaniecki, T. S., Corder, C. N., McDonald, R. H. \& Feldman, J. A. (1978), J. Lab. Clin. Med. 90, 604-612.

17. Rentzhog, L. (1972), Acta Physiol. Scand. Suppl. 377/1, 8-29.

18. Kaiser, H. (1965), Z. Analyt. Chem. 209, 1-18.

19. Carruthers, M., Taggart, P., Conway, N., Bates, D. \& Somerville, W. (1970), Lancet II, 62-67.

Prof. Dr. Dr. H. Wisser Department of Clinical Chemistry Robert-Bosch-Krankenhaus Auerbachstr. 110

D-7000 Stuttgart 50 
.

. 